\title{
Kroniek
}

\section{Kroniek concentratiecontrole 2020}

\author{
Bart de Rijke en Vivian van Weperen*
}

\author{
De cijfers ${ }^{1}$
}

\section{Inleiding}

De Kroniek concentratiecontrole 2020 beschrijft de belangrijkste ontwikkelingen op het gebied van concentratiecontrole in Nederland in 2020. Zoals gebruikelijk begint de kroniek met een overzicht van de belangrijkste cijfers, gevolgd door een overzicht van de belangrijkste veranderingen in de toepasselijke wet- en regelgeving. Vervolgens komen de sancties en rechtspraak en besluiten van de Autoriteit Consument \& Markt (ACM) in de meldingsfase en vergunningsfase aan bod. In 2020 heeft de COVID-19-pandemie voor diverse sectoren verstrekkende gevolgen gehad. Het is dan ook niet verrassend dat de ACM werd geconfronteerd met de vraag hoe de uitwerking van COVID-19 moet worden meegenomen in de beoordeling van een concentratie. Opvallend is voorts dat er relatief veel zaken in eerste instantie zijn gemeld bij de Europese Commissie en vervolgens op haar verzoek naar de ACM zijn verwezen.

Mr. B. de Rijke is partner en advocaat bij De Brauw Blackstone Westbroek in Amsterdam en Brussel. Mr. V.Y.H. van Weperen is advocaat bij De Brauw Blackstone Westbroek in Amsterdam. De auteurs (en/of hun kantoorgenoten) zijn in een aantal van de besproken zaken betrokken als advocaat.

1. Het jaarverslag van de ACM voor 2020 is nog niet gepubliceerd. Dit overzicht bevat daarom voorlopige, nog niet door de ACM gepubliceerde cijfers.

\begin{tabular}{ll}
$\begin{array}{l}\text { Meldingen van fusies, overnames en joint ventures } \\
\text { (concentraties) }\end{array}$ & 89 \\
\hline $\begin{array}{l}\text { Aantal gemelde fusies die niet meldingsplichtig } \\
\text { waren }\end{array}$ & 0 \\
\hline Ingetrokken meldingen & 1 \\
\hline Verleende ontheffingen & 1 \\
\hline Besluiten ACM op meldingen van concentraties & 90 \\
\hline Vergunningseisen ACM voor concentraties & 3 \\
\hline Vergunningsaanvragen & 4 \\
\hline Ingetrokken vergunningsaanvragen & 1 \\
\hline Besluiten ACM op vergunningsaanvraag & 6
\end{tabular}

\section{Wetgeving, informele zienswijzen en ontheffingen}

In 2020 hebben zich voor wat betreft het Nederlandse concentratietoezicht geen relevante wetswijzigingen voorgedaan. Ook heeft de ACM geen informele zienswijzen afgegeven met betrekking tot de toepassing van de regels van het concentratietoezicht. De ACM heeft in 2020 slechts één ontheffing verleend van de verplichting uit artikel 34 Mededingingswet (Mw) om na de melding van een concentratie een wachtperiode van vier weken in acht te nemen. Dit is enigszins opvallend, aangezien aan het begin van de COVID-19-crisis de algemene verwachting was dat veel bedrijven in (financiële) nood 
zouden komen, hetgeen zou kunnen leiden tot een golf aan overnames waarvoor een beroep op een ontheffing van de standstill-verplichting nodig zou zijn.

\section{Sancties en rechtspraak}

De ACM heeft in 2020 geen boetes opgelegd voor overtreding van de standstill-verplichting of voor andere overtredingen van de regels betreffende het concentratietoezicht. Er was in 2020 één gerechtelijke uitspraak inzake het concentratietoezicht waarbij de ACM betrokken was. In deze zaak heeft het College van Beroep voor het bedrijfsleven $(\mathrm{CBb})$ uitspraak gedaan, die positief heeft uitgepakt voor de ACM.

\section{ACM/Stichting Speel Verantwoord}

De enige gerechtelijke uitspraak over het concentratietoezicht in 2020 betreft een uitspraak van het $\mathrm{CBb}$ van 10 november 2020. Deze uitspraak ziet op een hoger beroep dat was ingesteld door Stichting Speel Verantwoord (SSV) en richt zich tegen de door de ACM goedgekeurde concentratie tussen Stichting Exploitatie Nederlandse Staatsloterij (SENS) en Stichting de Nationale Sporttotalisator (SNS). De uitspraak van het $\mathrm{CBb}$ kent een lange voorgeschiedenis: het vergunningsbesluit van de ACM dateert namelijk van 7 december 2015. Bij zowel het besluit van de ACM als de uitspraak van de rechtbank Rotterdam is in eerdere edities van dit tijdschrift uitgebreid stilgestaan. Voor de bespreking van deze uitspraak in hoger beroep is met name relevant dat de ACM in 2015 - zoals niet ongebruikelijk is - de exacte productafbakening in het midden heeft gelaten, waarbij zij nog wel heeft opgemerkt dat het meest aannemelijk is dat sprake is van een markt voor loterijen en lottospelen. Hoewel SENS en SNS een gezamenlijk marktaandeel van $52 \%$ behalen, achtte de ACM het niet aannemelijk dat de concentratie zou leiden tot een significante beperking van de mededinging, aangezien niet, of slechts in geringe mate, sprake zou zijn van concurrentie tussen lottospelen en loterijen. In deze beoordeling speelde de sterke regulering van de Nederlandse kansspelmarkt door de Wet op de kansspelen (Wok) een belangrijke rol. Het regelgevend kader, dat mede als doel heeft kansspelverslaving te voorkomen, heeft namelijk een concurrentiedempende werking op de Nederlandse kansspelmarkt aangezien een aanbieder voornamelijk in zijn eigen segment actief is. $\mathrm{Nu}$ ook in de situatie vóór de concentratie daarom reeds sprake was van geringe concurrentie tussen partijen, zou de concentratie volgens de ACM niet leiden tot significante negatieve effecten.

Alvorens in te gaan op de inhoudelijke beroepsgronden behandelt het $\mathrm{CBb}$ allereerst de stelling van $\mathrm{SSV}$ dat de rechter-commissaris van de rechtbank ten onrechte de vertrouwelijkheidsclaims van de ACM heeft gesanctioneerd. Volgens SSV had de ACM, dan wel de rechtbank, een zekere mate van toegang moeten faciliteren voor de meer dan zeshonderd interne documenten die als vertrouwelijk waren aangemerkt, desnoods door het opstellen van niet-vertrouwelijke samenvattingen. Hoewel het $\mathrm{CBb}$ de vertrouwelijkheidsclaims van de ACM onderschrijft, erkent het College dat de grote hoeveelheid vertrouwelijke stukken de procespositie van SSV heeft bemoeilijkt. Opvallend is hierbij dat het $\mathrm{CBb}$ daarom in aanloop naar zijn eigen beoordeling het onderzoek heeft heropend om de ACM alsnog in de gelegenheid te stellen samenvattingen te maken van vertrouwelijke stukken en passages. Het lange tijdsverloop van deze procedure heeft hier ongetwijfeld mee te maken. Dit oordeel van het $\mathrm{CBb}$ roept echter wel de vraag op of (potentiële) concurrenten mogelijk te veel ruimte wordt gegeven om toegang te krijgen tot het dossier via het instellen van beroep en of de administratieve belasting voor de toezichthouder (of: de betrokken partijen zelf) niet te groot wordt met deze werkwijze.

Dan de inhoudelijke gronden. SSV voert ten eerste aan dat de rechtbank ten onrechte heeft geoordeeld dat de ACM niet was gehouden om tot een definitieve marktafbakening te komen. Volgens SSV zou het besluit van de ACM hierdoor onvoldoende gemotiveerd zijn en 'op een fundamenteel punt tegenstrijdigheden bevatten'. In dit kader probeert SSV het $\mathrm{CBb}$ ervan te overtuigen dat het oordeel van de ACM dat de relevante markt waarschijnlijk loterijen en lottospelen omvat, zich niet verdraagt met haar uiteindelijke conclusie. Immers, als lottospelen en loterijen inderdaad tot dezelfde markt zouden behoren, dan duidt dit op vraagsubstitutie tussen lottospelen en loterijen, aldus SSV. Dit zou dan onverenigbaar zijn met de conclusie van de ACM dat SENS en SNS juist vanwege een gebrek aan vraagsubstitutie tussen lottospelen en loterijen niet (of slechts in geringe mate) met elkaar zouden concurreren. SSV gaat er echter aan voorbij dat een gebrek aan concurrentie ofwel kan betekenen dat partijen actief zijn op andere markten, ofwel erop kan duiden dat, hoewel actief op dezelfde markt, die markt zodanig heterogeen is dat partijen geen of nauwelijks concurrentiedruk op elkaar uitoefenen. De stelling van SSV is daarom te kort door de bocht en het $\mathrm{CBb}$ gaat hier ook niet in mee. Tussen partijen is niet in geschil dat op mogelijke separate productmarkten de concentratie geen significant effect zou hebben op de mededinging. Ook voor het geval partijen actief zouden zijn op dezelfde markt, heeft de ACM naar het oordeel van het $\mathrm{CBb}$ conform artikel $42 \mathrm{Mw}$ de gevolgen van de concentratie voldoende onderzocht een definitieve marktafbakening is voor deze beoordeling niet nodig. Deze beroepsgrond van SSV slaagt daarom niet. Een ander oordeel van het $\mathrm{CBb}$ zou niet alleen verstrekkende gevolgen hebben gehad voor de beslissingspraktijk van de ACM - het is immers meer uitzondering dan regel dat de ACM daadwerkelijk overgaat tot het afbakenen van een relevante productmarkt het zou ook op gespannen voet hebben gestaan met het gegeven dat marktafbakening geen doel op zich is, maar slechts een hulpmiddel voor het beoordelen van de gevolgen van een concentratie.

SSV bestrijdt ten tweede het oordeel van de rechtbank dat de ACM terecht als uitgangspunt heeft genomen dat 
de concurrentie op de kansspelmarkt wordt gedempt door de regulering op grond van de Wok en zij stelt dat de ACM onvoldoende aannemelijk heeft gemaakt dat een gezamenlijk marktaandeel van $52 \%$ niet leidt tot mededingingsbezwaren. Volgens SSV hadden de rechtbank en de ACM in het regulerend kader juist een reden moeten zien om de gereduceerde vorm van concurrentie in de markt te beschermen. SSV slaat volgens het $\mathrm{CBb}$ met deze redenering echter tweemaal de plank mis. Allereerst gaat SSV eraan voorbij dat de regulering, en de gedempte concurrentie in de markt, er juist aan bijdraagt dat de concurrentiedruk op de aanwezige spelers zowel voor als ná de concentratie niet significant anders is. Ook vóór de concentratie waren SENS, SNS en de goededoelenloterijen ieder primair actief in hun eigen marktsegment en de regulering heeft ook na de concentratie een dempende werking op de mogelijkheid voor partijen om concurrentieparameters te verslechteren. Ten tweede suggereert SSV ten onrechte dat de ACM een zwaardere toets zou moeten aanleggen in die gevallen waarin door regulering sprake is van verminderde concurrentie in de markt. Een dergelijke verplichting volgt echter niet uit artikel 41 lid $2 \mathrm{Mw}$, zo benadrukt ook het $\mathrm{CBb}$. Ook deze beroepsgrond slaagt daarom niet.

De laatste beroepsgrond van SSV ziet op de online markt. Hoewel ten tijde van het vergunningsbesluit nog geenszins sprake was van (legale) online kansspelen - de Wet kansspelen op afstand is pas op 1 april van dit jaar in werking getreden - bestrijdt SSV het oordeel van de rechtbank dat de ACM terecht onvoldoende waarschijnlijk heeft geacht dat de fuseerde onderneming haar marktmacht zou kunnen overhevelen naar het nieuwe online segment. Zowel de ACM als het $\mathrm{CBb}$ acht het in dit kader relevant dat de spelersgroepen offline en online van elkaar verschillen en dat grote buitenlandse aanbieders al ruime ervaring hebben met het aanbieden van online casinospelen en sportweddenschappen. Gelet op onder meer deze omstandigheden oordeelt het $\mathrm{CBb}$ daarom dat de ACM terecht heeft overwogen dat het niet aannemelijk is dat SENS en SNS als gevolg van de concentratie in staat zullen zijn om hun positie in loterijen en lottospelen in te zetten op het gebied van de toekomstige online casinospelen en sportweddenschappen, zodanig dat dit tot een significante belemmering van de mededinging zou leiden. $\mathrm{Nu}$ ook deze laatste beroepsgrond niet slaagt, verklaart het $\mathrm{CBb}$ het hoger beroep van SSV ongegrond.

\section{Meldingen en vergunningsaanvragen}

In het afgelopen jaar heeft de ACM zoals gewoonlijk verreweg de meeste concentraties in de meldingsfase goedgekeurd. Daarbij heeft de ACM de overgrote meerderheid van de besluiten verkort afgedaan: van de negentig besluiten die de ACM in de meldingsfase heeft goedgekeurd bevatten twaalf besluiten een inhoudelijke beoordeling.

\section{Meldingsfase}

In dit onderdeel gaan wij in op twee goedkeuringsbesluiten van de ACM in de meldingsfase. Een aantal andere besluiten van de ACM in de meldingsfase die niet verkort zijn afgedaan laten wij in deze kroniek onbesproken. ${ }^{2}$

DPG Media/Sanoma Media

Op 10 april 2020 heeft de ACM de overname van Sanoma Media B.V. (Sanoma) door DPG Media B.V. (DPG) goedgekeurd. DPG is in Nederland vooral bekend als uitgever van diverse nationale en regionale dagbladen zoals het AD, Trouw, de Gelderlander en het Brabants Dagblad. DPG is daarnaast ook aanbieder van online diensten op onder andere het gebied van prijsvergelijking (Independer.nl) en arbeidscommunicatie (Intermediair.nl en NationaleVacaturebank.nl). Sanoma is uitgever van weekbladen, waaronder Donald Duck, Margriet, Libelle en VIVA, en via Aldipress eveneens actief in de distributie en trademarketing van tijdschriften, romans en puzzels die bestemd zijn voor de losse verkoop. Net als DPG is Sanoma ook actief als aanbieder van online nieuws, namelijk via de website en app NU.nl.

De beoordeling van deze concentratie is niet alleen interessant vanuit een mededingingsrechtelijk perspectief, maar raakt ook aan maatschappelijke vraagstukken zoals verschraling van het nieuwsaanbod en mediapluriformiteit. Dat de ACM ook hieraan aandacht heeft besteed, blijkt onder meer uit het feit dat zij tijdens haar marktonderzoek heeft gesproken met de Nederlandse Vereniging van Journalisten, de Auteursbond en het Commissariaat voor de Media. Bovendien bevindt de mediasector zich in een digitale transitie, waardoor de dynamiek van de mediasector de laatste jaren is veranderd. 'Traditionele' media zoals dagbladen en tijdschriften verliezen aan terrein ten opzichte van het online segment, en het belang van data - om zowel gericht te kunnen adverteren als content te kunnen afstemmen op de consument - is steeds groter geworden.

De activiteiten van partijen overlappen op het gebied van het aanbieden van algemeen online nieuws en het aanbieden van online ruimte voor advertenties. De digi-

2. Het gaat hierbij om de meldingsbesluiten van de ACM in Audax Groep B.V/Bruna B.V (zaak ACM/19/037542), KidsFoundation Holdings B.V./ Partou Holding B.V. (zaak ACM/19/035829), Digital Realty Trust Inc./ InterXion Holding N.V. (zaak ACM/19/038019), GVB Holding N.V., HTM personenvervoer N.V., NS Groep N.V. en Rotterdamse Electrische Tram N.V. (zaak ACM/20/039644), Hutchison Ports Netherlands B.V./ APM Terminals Rotterdam B.V. (zaak ACM/20/040727), Mediahuis Noord-Nederland B.V. FBJM Media Holding B.V. (NDC Mediagroep) Mediahuis NV (zaak ACM/20/042189). Om een zo divers mogelijk palet aan besluiten ten aanzien van zo veel mogelijk verschillende sectoren te kunnen behandelen (ook met het oog op de kroniek van voorgaande jaren), laten wij de voornoemde meldingsbesluiten onbesproken. 
talisering van de mediasector en het feit dat partijen actief zijn in een breed scala aan online activiteiten - die veelal met elkaar zijn verweven - moet ongetwijfeld de exercitie van de marktafbakening hebben bemoeilijkt. Opvallend is namelijk dat, anders dan andere concentratiebesluiten, de ACM uitdrukkelijk benoemt dat het afbakenen van de relevante marketen geen doel op zichzelf is, maar een hulpmiddel voor de beoordeling van de effecten van de concentratie op de mededinging. ${ }^{3}$

De ACM en de Europese Commissie (Commissie) hebben niet eerder een aparte productmarkt afgebakend voor het aanbieden van (onbetaald) algemeen online nieuws. In haar marktonderzoek besteedt de ACM aandacht aan de vraag in hoeverre het online nieuws verschilt van het printaanbod, waarbij zij concludeert dat tussen beide grote inhoudelijke verschillen bestaan, vooral voor wat betreft de timing en de mate van achtergrond, opinie en kleuring. Voor haar inhoudelijke beoordeling gaat de ACM daarom uit van een markt voor algemeen online nieuws in Nederland, waarbij de ACM in het midden laat of er een nader onderscheid moet worden gemaakt tussen betaald en onbetaald online nieuws.

Gelet op de activiteiten van partijen heeft de ACM ook beoordeeld in hoeverre het anbieden van online advertentieruimte nog nader zou moeten worden gesegmenteerd. In navolging van eerdere precedenten gaat de ACM uit van nationale (of ruimere) markten voor (1) online advertenties, (2) online personeelsadvertenties, (3) advertenties in landelijke en regionale dagbladen, (4) advertenties in regionale dagbladen en huisaan-huisbladen, (5) advertenties in (publieks)tijdschriften en (6) advertenties op de radio. Ten slotte gaat de $\mathrm{ACM}$, in navolging van de beoordeling van de Commissie in Google Search (Shopping), uit van een nationale markt voor prijsvergelijkingsdiensten, met een mogelijk onderscheid naar productgroep als de meest waarschijnlijke relevante productmarkt.

In de inhoudelijke beoordeling staat de ACM uitgebreid stil bij de vraag of de samenvoeging van twee onafhankelijke mediabedrijven kan resulteren in een verschraling van het aanbod van online algemeen nieuws of een vermindering van de kwaliteit van dit nieuws. Hoewel DPG en Sanoma nabije concurrenten zijn en hun gezamenlijk positie op het gebied van algemeen online nieuws redelijk groot wordt (het gezamenlijke (volume)aandeel ligt rond 30-40\%), acht de ACM dit uiteindelijk niet aannemelijk. Onder andere NOS, Mediahuis (Telegraaf) en RTL zijn sterke spelers op het gebied van algemeen nieuws, waarvan voldoende disciplinerende werking zal blijven uitgaan. Ook is de rol van Google en Facebook niet onbelangrijk: door hun aggregator-functie bieden zij lezers een platform om over te stappen tussen nieuws van verschillende aanbieders en oefenen hiermee indirecte druk uit op partijen. De ACM concludeert dan ook dat de concentratie niet zal resulteren in een signifi-

3. Zie voor wat betreft de discussie over het belang van marktafbakening ook M. Visser, 'Marktafbakening. Best belangrijk', M\&M 2020/6. cante beperking van de mededinging op de mogelijke markt voor onbetaald algemeen nieuws.

De beoordeling van de gevolgen voor het aanbieden van online advertenties kan de ACM eenvoudig afdoen. Internationale platforms (Google, Facebook) maken met een marktaandeel van circa $70 \%$ op deze markt de dienst uit en partijen hebben gezamenlijk een beperkt marktaandeel van $0-10 \%$. De ACM acht het dan ook niet aannemelijk dat de concentratie de daadwerkelijke mededinging op deze markt significant zal belemmeren. Voorts heeft de ACM nog een vijftal niet-horizontale gevolgen van de concentratie onderzocht. Deze risico's zien ten eerste op het overhevelen van marktmacht: van algemeen online nieuws naar betaald algemeen online nieuws en prijsvergelijkingsdiensten en daarnaast van enige advertentiemarkt naar anpalende advertentiemarkten. Ten aanzien van deze risico's concludeert de ACM ten eerste dat het toenemende bereik van DPG op algemeen online nieuws (door NU.nl) onvoldoende is om concurrenten van betaald online nieuws uit te sluiten. Het percentage betalende consumenten voor online nieuws is nog relatief laag (slechts $12 \%$ in 2019) en eerdere ervaringen van partijen met de conversie van bezoekers van gratis nieuwssites naar een betaalde propositie zijn over het algemeen slecht. Ook ten aanzien van de overige niet-horizontale risico's concludeert de ACM dat het toegenomen bereik van DPG onvoldoende aanleiding geeft om aan te nemen dat zij de mededinging op de markt voor prijsvergelijkingsdiensten en advertentiemarkten kan beperken.

Ten slotte is bijzonder dat de ACM op de inkoopmarkt de positie van (freelance) journalisten uitdrukkelijk onderzocht. Zowel de Vereniging voor Journalisten als de Auteursbond zag mogelijke problemen als gevolg van de concentratie, met name in de mogelijkheden voor journalisten om redelijke tarieven te kunnen hanteren voor het verlenen van hun diensten. Dit speelt tegen de achtergrond van een bredere discussie over de arbeidsmarktpositie van zzp'ers waar ook de ACM oog voor heeft. ${ }^{4}$ De ACM concludeert uiteindelijk dat zowel gelet op de verscheidenheid van expertises en functies van de journalisten binnen de twee bedrijven en het feit dat DPG ook na de overname een beperkte positie zal blijven innemen voor wat betreft de inkoop van (freelance) journalistieke diensten, de overname geen grote invloed zal hebben op de onderhandelingspositie van freelance journalisten. Gelet op al het bovenstaande geeft de ACM daarom haar goedkeuring voor de concentratie tussen DPG en Sanoma.

NS Groep N.V./Pon Netherlands B.V.

Op 20 mei 2020 heeft de ACM onder voorwaarden haar goedkeuring verleend voor de oprichting van een gemeenschappelijke onderneming (GO) door NS Groep N.V. (NS) en Pon Netherlands B.V. (Pon). Partijen hadden deze concentratie in eerste instantie bij de Commissie gemeld. $\mathrm{Na}$ een verwijzingsverzoek van de ACM

4. Zie in dit kader bijvoorbeeld ook de Leidraad tariefafspraken zzp'ers van de ACM (www.acm.nl/sites/default/files/documents/2020-07/ leidraad-tariefafspraken-zzper.pdf). 
heeft de Commissie op 15 januari 2020 de concentratie naar de ACM verwezen. Het besluit in NS/Pon biedt nader inzicht in de manier waarop de ACM digitale concentraties beoordeelt.

De door NS en Pon op te richten GO zal actief worden op het gebied van (deel)mobiliteitsdienstverlening. Deelmobiliteitsdienstverlening - een relatief nieuwe dienst - betreft zowel deelvervoersdiensten ${ }^{5}$ als mobiliteitsdiensten, die het gebruik van (openbaar)vervoersdiensten kunnen vergemakkelijken. Een voorbeeld van een mobiliteitsdienst is het Mobility as a Service (MaaS-)concept, waarbij reizigers doorgaans via een app een volledige reis met verschillende vervoersmodaliteiten kunnen plannen, boeken en betalen.

NS en Pon zijn beide actief op het gebied van (deel)vervoer en mobiliteit. NS is als houder van het hoofdrailnetwerk (HRN) vanzelfsprekend de grootste aanbieder van openbaar vervoer per trein in Nederland. Daarnaast exploiteert NS de bij ieder bekende gele OVfiets en is zij ook via haar dochteronderneming Hely ${ }^{6}$ - een MaaS-platorm - actief op het gebied van deelvervoersdienstverlening. Pon is primair actief op het produceren en importeren van diverse elektrische vervoermiddelen en vormt hiermee een belangrijke input voor het aanbieden van mobiliteitsdiensten. Daarnaast heeft Pon een (indirect) belang in Collect Car B.V. (de exploitant van het Greenwheels-autodeelconcept) en biedt zij via haar dochteronderneming $\mathrm{Next}^{7}$ (eveneens een MaaS-platform) verschillende deelvervoers- en mobiliteitsdiensten aan. De GO die NS en Pon willen oprichten heeft als doel de diensten van Next en Hely te combineren om het deelmobiliteitsconcept verder te ontwikkelen en zal zich in eerste instantie vooral richten op het via een app aanbieden van (e-)fietsen, (e-)auto's en (e-)bakfietsen via hubs en de integratie van (deel)vervoersdiensten van derde partijen.

Partijen zijn actief op verschillende markten. Ten eerste zijn partijen zelf actief op de markt voor het aanbieden van (e-)deelfietsen aan het algemene publiek en de markt voor het aanbieden van (deel)auto's. NS is daarnaast ook actief op de markt voor het aanbieden van treinvervoer van passagiers binnen de HRN-concessie.

Ten aanzien van zowel de lokale markt voor het aanbieden van (e-)deelfietsen als de regionale of nationale markt voor het aanbieden van deelauto's voorziet de ACM geen mededingingsproblemen. Hierbij is nog wel relevant dat de ACM niet alleen heeft gekeken naar de positie van Hely en Next op de markt voor het aanbieden van (e-)deelfietsen, maar ook rekening heeft gehouden met de sterke positie van de OV-fiets; het is volgens de ACM niet aannemelijk dat NS via de OV-fiets de concurrentie zal aangaan met de activiteiten van de op te richten GO. Hoewel partijen, inclusief het aanbod van de OV-fiets, in Amsterdam een marktaandeel van $60-70 \%$ behalen, bedraagt de toevoeging van Hely

5. Auto's, fietsen of scooters die consumenten voor korte duur en veelal via een digitaal platform kunnen huren.

Mobility Solutions and Services B.V.

Next Urban Mobility B.V. slechts $0-10 \%$. Dit geeft de ACM onvoldoende aanleiding tot zorgen.

Het zwaartepunt van de beoordeling van de ACM ligt bij de analyse van de (retail)markt voor het geïntegreerd aanbieden van vervoers- en mobiliteitsdiensten via een app. Voor wat betreft de afbakening van deze markt liggen de opvattingen van de ACM niet helemaal op één lijn met die van partijen en van de Commissie. Partijen stellen zich op het standpunt dat moet worden uitgegaan van een retailmarkt voor de distributie van vervoers- en mobiliteitsdiensten door middel van een app. Partijen betogen, in lijn met de overwegingen van de Commissie in de verwijzingsbeschikking, dat hun diensten niet alleen concurreren met vergelijkbare, geïntegreerde MaaS-oplossingen, maar ook met de diensten van andere vervoers- en mobiliteitsaanbieders die één enkele modaliteit aanbieden via een app. De ACM gaat echter uit van een nauwere markt. Volgens de ACM is het $o p$ dit moment zo dat geïntegreerde MaaS-apps niet alleen met elkaar concurreren, maar ook met unimodale aanbieders. ${ }^{8}$ Anders dan de Commissie benadrukt de ACM echter uitdrukkelijk dat geintegreerde MaaSoplossingen binnen afzienbare tijd als een afzonderlijke markt kunnen worden beschouwd. Alle bestaande MaaS-diensten zijn er immers op gericht om de 'bundel' van mobiliteitsdiensten steeds verder uit te breiden om uiteindelijk één compleet en geintegreerd mobiliteitsaanbod voor reizigers te creëren. Dit doel volgt ook uit interne stukken van partijen. Om deze reden gaat de ACM uit van een markt voor het geïntegreerd aanbieden van vervoers- en mobiliteitsdiensten via een app.

Voor wat betreft de horizontale gevolgen voorziet de ACM geen problemen op deze markt. De markt is nog volop in ontwikkeling en partijen nemen een zeer geringe positie in $(0-5 \%)$.

Ondanks de geringe positie van partijen op de markt voor het geintegreerd aanbieden van vervoers- en mobiliteitsdiensten, acht de ACM het wel degelijk aannemelijk dat partijen zowel de mogelijkheid als de prikkel hebben om na de concentratie een partiële bronafschermingsstrategie te volgen en de concurrenten van de GO onder slechtere voorwaarden toegang kunnen geven tot het treinvervoer op het HRN en (e-)deelfietsen. Juist nu treindiensten en de OV-fiets belangrijke of zelfs essentiële - inputfactoren zijn voor een MaaSaanbod, zullen andere MaaS-aanbieders deze diensten hoe dan ook als input willen blijven afnemen. De GO heeft, anders dan partijen hadden betoogd, daarom wel degelijk een prikkel om een partiële bronafschermingsstrategie toe te passen. Als het verschil in aantrekkelijkheid tussen de GO en overige aanbieders door een afschermingsstrategie groot genoeg wordt, kan dit zelfs leiden tot overstap van gebruikers van alternatieve MaaS-platforms naar de app van de GO, waardoor de $\mathrm{GO}$ additionele opbrengsten kan realiseren en haar posi-

8. Een reiziger kan op dit moment namelijk (1) rechtstreeks gebruikmaken van de app of website van een vervoerder, (2) een reisplanner consulteren en vervolgens de (losse onderdelen van de) reis via de vervoerder boeken en betalen of (3) gebruikmaken van een geïntegreerde MaaSoplossing. 
tie op de downstreammarkt zou versterken. Een belangrijk deel van de markt zou bovendien in potentie geraakt kunnen worden en de ACM acht het dan ook aannemelijk dat de mededinging op de downstreammarkt als gevolg van de partiële bronafschermingsstrategie kan worden belemmerd.

De ACM heeft daarnaast ook onderzocht of er een risico bestaat op klantafscherming met betrekking tot deelfietsen en deelauto's. De ACM gaat uiteindelijk mee in het betoog van partijen dat het belang van de GO als distributiekanaal voor andere aanbieders van deelfietsen en deelauto's op dit moment beperkt is. Er zijn op dit moment voor concurrerende aanbieders van mobiliteitsdiensten bovendien voldoende alternatieve mogelijkheden om hun diensten op te nemen in met de GO concurrerende MaaS-platforms. De ACM acht een dergelijke klantafschermingsstrategie daarom niet aannemelijk.

Ondanks de op dit moment beperkte positie van de GO hebben partijen bepaalde toezeggingen moeten doen om de mededingingsbezwaren van de ACM weg te nemen. De verbintenissen van partijen houden in dat voor de duur van de GO - voor zover NS de OV-fiets en/of het treinvervoer app-enabled maakt in de GO - deze diensten niet onder minder gunstige voorwaarden zullen worden geleverd aan concurrenten van de GO. Bovendien zeggen partijen toe dat de informatie die door NS beschikbaar wordt gesteld aan de GO en haar concurrenten van dezelfde kwaliteit is, binnen eenzelfde tijdbestek beschikbaar wordt gemaakt en dat tussen de GO en de concurrenten niet onderling wordt gediscrimineerd. Een Monitoring Trustee zal jaarlijks rapporteren of partijen de toezeggingen naleven.

De markt reageert niet onverdeeld positief op de door partijen voorgestelde toezeggingen. Volgens marktpartijen is het geven van toegang onder gelijke commerciële voorwaarden onvoldoende om een gelijk speelveld te creëren voor concurrenten. Bovendien zouden de toezeggingen NS en Pon nog de mogelijkheid geven om onaantrekkelijke voorwaarden aan de GO op te leggen en dan dus ook aan concurrenten van de GO, omdat dit zou kunnen worden gecompenseerd via NS en Pon. De ACM acht het echter niet aannemelijk dat Pon een prikkel zou hebben om de marges van de GO opzettelijk laag te houden, aangezien Pon geen mogelijkheid heeft tot kruissubsidiëring. Hoewel een dergelijke strategie met betrekking tot de OV-fiets en treindiensten baten zou opleveren voor NS, geldt dit niet voor Pon. De ACM concludeert dan ook dat de toezeggingen van partijen de door haar geconstateerde mededingingsproblemen wegneemt en bovendien uitvoerbaar en handhaafbaar is. De ACM keurt de concentratie goed.

\section{Vergunningsfase}

De ACM heeft in 2020 maar liefst zes concentraties in de vergunningsfase beoordeeld, waarvan er drie zien op de zorgsector. ${ }^{9}$ Dit is opvallend, aangezien dit aantal in voorgaande jaren een stuk lager lag.

Triton (Sunweb)/Corendon

Op 26 oktober 2020 heeft de ACM een vergunning verleend voor de overname van Corendon Holding B.V. (Corendon) door Sunweb. Partijen hadden de concentratie in eerste instantie bij de Commissie gemeld, maar vanwege de mogelijke gevolgen voor de Nederlandse markt heeft de ACM de Commissie om gedeeltelijke verwijzing verzocht. Om eenzelfde reden heeft de Belgische Mededingingsautoriteit (BMA) de Commissie eveneens om gedeeltelijke verwijzing verzocht en de concentratie op 10 augustus 2020 na een vereenvoudigde procedure goedgekeurd.

Sunweb en Corendon zijn beide touroperators die pakketreizen aanbieden vanuit onder meer Nederland en België naar diverse, veelal zonnige, bestemmingen. In het meldingsbesluit van 13 juli 2020 uitte de ACM haar zorgen over deze voorgenomen concentratie. Naast partijen is TUI namelijk de enige andere grote touroperator die actief is in Nederland en de ACM sloot dan ook niet uit dat de concentratie zou kunnen resulteren in een significante beperking van de mededinging op deze - toen al - oligopolistische markt. In de vergunningsfase heeft de ACM daarom uitgebreid onderzocht of de overname de concurrentie zou beperken, met stijgende prijzen en een dalende kwaliteit als gevolg.

Het is voor de lezers van dit tijdschrift bekend dat voor de beoordeling van de mededingingsgevolgen van een concentratie, de situatie die als gevolg van een concentratie ontstaat wordt vergeleken met die situatie die zonder de concentratie zou hebben bestaan. Voor de onderhavige concentratie moest de ACM daarom ook beoordelen in hoeverre zij de gevolgen van de COVID-19-crisis zou moeten meenemen in haar analyse. De reis- en de luchtvaartsector zijn immers vanaf medio maart 2020 zo goed als stil komen te liggen. De ACM concludeert uiteindelijk dat de gevolgen en de eventuele structurele aard van de gevolgen van de COVID-19-crisis onvoldoende zeker zijn om mee te nemen. Bovendien hebben marktpartijen aangegeven te verwachten dat de markt zich volledig zal herstellen na twee tot drie jaar. Daarom gaat de ACM, evenals in het meldingsbesluit, uit van de situatie van vóor COVID-19.

In de meldingsfase overwoog de ACM dat zij over onvoldoende informatie beschikte om te kunnen concluderen of sprake is van een aparte productmarkt voor pakketreizen voor zonvakanties naar bestemmingen op korte en middellange afstand (hierna: zonvakanties), of van een ruimere markt die ook losse reiscomponenten omvat. Consumenten kunnen naast pakketreizen immers ook de vluchten naar en accommodaties op een bepaalde bestemming 'los' aanschaffen via accommodatieplatforms zoals Booking.com en Trivago. Om meer

9. De vergunningsbesluiten van de $A C M$ in Koninklijke BAM Groep N.V./ Heijmans N.V. (zaak ACM/19/036914) en Stichting De Riethorst Stromenland/ Stichting Volckaert/Stichting Schakelring (zaak ACM/ 19/037511) laten wij hier onbesproken. 
duidelijkheid te verkrijgen over de onderlinge inwisselbaarheid van pakketreizen en de losse componenten, heeft de ACM in de vergunningsfase niet alleen gesproken met (nog meer) marktpartijen, maar ook een consumentenkeuzeproces-onderzoek laten uitvoeren door Panteia. De opvattingen van marktpartijen gaven echter geen eenduidig beeld. TUI, naast Corendon en Sunweb de grootste touroperator in Nederland, stelde bijvoorbeeld enerzijds wel degelijk concurrentiedruk te ervaren vanuit platforms zoals Booking.com. Anderzijds stelt zowel TUI als Prijsvrij ook dat consumenten bewust kiezen voor pakketreizen, omdat zij willen worden 'ontzorgd'. Losse reiscomponenten voorzien niet in ditzelfde gemak. Het onderzoek van Panteia brengt uiteindelijk wel de benodigde duidelijkheid. Uit dat onderzoek volgt dat, hoewel afnemers van pakketreizen vaker voor een gunstiger aanbod naar een andere pakketreisaanbieders kijken (67\%), zo'n 30\% van de afnemers daarvoor ook naar losse reiscomponenten kijkt. Bovendien zou 38\% van de consumenten pakketreizen en losse componenten zelfs als alternatieven beschouwen. Op basis hiervan concludeert de ACM dat reiscomponenten inderdaad in voldoende mate concurrentiedruk uitoefenen op pakketreizen.

De ACM heeft ook nog beoordeeld of een nader onderscheid moet worden gemaakt op basis van de bestemming van de zonvakantie. Volgens partijen geeft echter voor consumenten de prijs-kwaliteitverhouding de doorslag en niet de bestemming, wat door het marktonderzoek wordt bevestigd. De ACM concludeert daarom dat sprake is van een relevante productmarkt voor zonvakanties naar bestemmingen op de korte en middellange afstand, zonder nader onderscheid naar bestemming. De ACM had in de meldingsfase reeds geconcludeerd dat deze markt nationaal van aard is.

Alvorens in te gaan op de inhoudelijke beoordeling heeft de ACM eerst de marktaandelen op de ruimere nationale markt voor zonvakanties en de nauwere nationale markt voor pakketreizen bekeken. Op de ruimere markt voor zonvakanties voorziet de ACM geen problemen. $\mathrm{Na}$ de concentratie zouden partijen slechts een marktaandeel van $0-10 \%$ hebben, waardoor de ACM de gevolgen op deze ruimere markt niet nader onderzoekt. De ACM onderzoekt wel de gevolgen van de concentratie op de nauwere markt voor pakketreizen, waar partijen een marktaandeel van $40-50 \%$ zouden behalen en TUI als enige andere grotere speler zou overblijven met een marktaandeel van $30-40 \%$.

Het is niet verrassend dat de ACM op voorhand kritisch was over de eventuele negatieve gevolgen van de overname van Corendon door Sunweb. Op de nauwere markt voor pakketreizen was immers al vóór de concentratie sprake van een oligopolie, waarbij marktpartijen bovendien hadden opgemerkt dat zij Sunweb en Corendon als nabije, of zelfs meest nabije, concurrenten van elkaar zagen. In de vergunningsfase oordeelt de ACM echter dat zij het niet aannemelijk acht dat partijen een economische machtspositie zullen verkrijgen op de mogelijke markt voor pakketreizen, met name vanwege de concurrentiedruk die uitgaat van losse reiscomponenten.
Ook zónder deze machtspositie resteert de ACM echter nog de taak om te beoordelen of desondanks sprake kan zijn van een significante belemmering van de daadwerkelijke concurrentie. Omdat het hier gaat om een oligopolistische markt, moet in het bijzonder worden beoordeeld of (1) belangrijke concurrentiedruk die partijen op elkaar uitoefenen wegvalt en (2) de concurrentiedruk op de overige concurrenten vermindert. De ACM concludeert dat beide omstandigheden zich niet voordoen.

Ten eerste komt uit het marktonderzoek in de vergunningsfase een ander beeld naar voren over het concurrentieel speelveld dan in de meldingsfase. Alle bevraagde marktpartijen geven in de vergunningsfase namelijk aan dat Sunweb, Corendon én TUI met elkaar concurreren en dat in de ogen van de consument de producten van deze drie touroperators onderling uitwisselbaar zijn. Opvallend is dat uit de data-analyse van de ACM (onder meer een kwantitatieve analyse van het verloop van afzet en prijzen van de drie touroperators) volgt dat TUI een nabijere concurrent is van zowel Sunweb als Corendon. Ten tweede acht de ACM het waarschijnlijk dat ook na de concentratie partijen concurrentiedruk zullen ervaren van zowel aanbieders van losse reiscomponenten als van andere pakketaanbieders die hun aanbod uitbreiden. Dat toetreding ook mogelijk is, blijkt uit de recente toetreding van Transavia en de plannen van Easyjet en Thomas Cook. Een significante prijsstijging zullen partijen volgens de ACM evenmin kunnen doorvoeren. Op basis van de uitgevoerde fusiesimulaties schat de ACM de indicatieve prijseffecten op een prijsstijging van $2 \%$, waarin bovendien de concurrentiedruk van losse reisaanbieders niet is meegenomen. De eerdere zorgen van de ACM worden in het onderzoek van de vergunningsfase dan ook ontkracht.

De ACM acht het ten slotte ook niet aannemelijk dat de concentratie zal leiden tot gecoördineerde effecten die de mededinging kunnen belemmeren, ondanks de gelijke omvang van TUI en partijen na de concentratie. Drie marktpartijen hadden hun zorgen geuit over mogelijke coördinatie en wezen in dit kader vooral op prijsafstemming tussen TUI en partijen. Een dergelijke coördinatiestrategie is volgens de ACM echter niet aannemelijk, gezien de grote hoeveelheid aan verschillende pakketreizen die partijen zouden moeten monitoren. Ook een impliciete afstemming die zou zien op het elimineren van overlap tussen partijen, bijvoorbeeld door het verdelen van zonbestemmingen, acht de ACM niet aannemelijk. Uit het marktonderzoek volgt immers dat consumenten bestemmingen veelal als onderling uitwisselbaar beschouwen en de marktposities van partijen zijn volgens de ACM niet zodanig dat kan worden aangenomen dat zij op een natuurlijke verdeling van bestemmingen zouden uitkomen, zonder hierover expliciete afspraken te maken.

Op basis van het bovenstaande besluit de ACM tot het verlenen van een vergunning voor de overname van Corendon door Sunweb. 
Thebe Wijkverpleging/Stichting Careyn in WestBrabant

Op 3 november 2020 heeft de ACM een vergunning onder voorwaarden verleend voor de overname van onderdelen van Stichting Careyn (Careyn) in West-Brabant door Thebe Wijkverpleging B.V. (Thebe). Thebe en Careyn zijn beide actief op het gebied van dagactiviteiten, wijkverpleging, thuisbegeleiding, terminale palliatieve zorg in een intramurele voorziening en personenalarmering. In het meldingsbesluit van 6 maart 2020 oordeelde de ACM al ten aanzien van thuisbegeleiding, personenalarmering en de terminale palliatieve zorg dat zij geen mededingingsproblemen voorzag. Vanwege het beperkte aantal andere actieve aanbieders voorzag de ACM echter wél mogelijke mededingingsproblemen ten aanzien van wijkverpleging in de gemeenten AlphenChaam, Baarle-Nassau en Breda. Eenzelfde risico constateert de ACM eveneens voor het verzorgen van dagactiviteiten aan ouderen en chronisch zieken in de gemeente Breda.

Bij de beoordeling van dagactiviteiten speelt voor de afbakening van de relevante markt de financieringswijze een bepalende rol. In Nederland worden dagactiviteiten aan ouderen namelijk gefinancierd vanuit de Wet langdurige zorg $(\mathrm{Wlz})$, waarvoor de gemeente zorg draagt, en vanuit de Wet maatschappelijke ondersteuning (Wmo), waarvoor een (regionaal) zorgkantoor verantwoordelijk is. In de vergunningsfase heeft de ACM nader onderzocht of sprake is van aparte productmarkten voor Wmo-gefinancierde dagactiviteiten enerzijds en Wlz-gefinancierde dagactiviteiten anderzijds. In voorgaande besluiten ${ }^{10}$ ging de ACM uit van aparte productmarkten, met name vanwege de zwaardere zorgbehoefte van Wlz-gefinancierde patiënten. Voor de beoordeling van deze concentratie wijkt de ACM hier echter van af. Doorslaggevend is hierbij dat het in eerdere besluiten geconstateerde gebrek aan substitueerbaarheid tussen Wmo- en Wlz-gefinancierde dagactiviteiten niet, of in ieder geval in veel minder sterke mate, opgaat voor de gemeente Breda: Wmo- en Wlz-cliënten nemen in gemengde groepen deel aan dagactiviteiten, die bovendien worden verzorgd door dezelfde medewerkers. Voor de beoordeling van deze concentratie moeten Wmogefinancierde en Wlz-gefinancierde dagactiviteiten daarom tot één markt voor dagactiviteiten worden gerekend. Hoewel de ACM vóór dit besluit nog niet eerder een geografische markt had afgebakend die zowel Wmoals Wlz-gefinancierde dagactiviteiten voor ouderen omvat, ${ }^{11}$ kijkt zij hiervoor zoals gebruikelijk naar de herkomstgegevens van partijen. Op basis hiervan conclu-

10. Zie bijvoorbeeld de besluiten van de ACM van 30 juni 2017 in zaak 17.0420.22, Stichting SHDH - Stichting Amie Ouderenzorg en het besluit van de ACM van 7 november 2019 in zaak ACM/19/035880, Stichting Schakelring - Stichting De Riethorst Stromenland - Stichting Volckaert.

11. Voor uitsluitend Wmo-gefinancierde dagactiviteiten aan ouderen is de geografische markt in eerdere besluiten afgebakend op het niveau van de inkopende gemeente of de inkopende aanbestedingsregio. Voor uitsluitend Wlz-gefinancierde dagactiviteiten is de markt eerder geografisch afgebakend op ten minste het niveau van de gemeente waarin partijen gevestigd zijn en ten hoogste de zorgkantoorregio. deert de ACM dat de gemeente Breda de relevante geografische markt is.

De zorgen van de ACM voor dagactiviteiten in Breda waren met name gebaseerd op het hoge gezamenlijke marktaandeel van partijen in $2018^{12}(50-60 \%$ voor $\mathrm{Wmo}, 40-50 \%$ voor $\mathrm{Wlz}$ en $50-60 \%$ voor $\mathrm{Wmo}$ en $\mathrm{Wlz}$ gezamenlijk). In het vergunningsbesluit komt de ACM hierop terug. Uit het onderzoek in de vergunningsfase is naar voren gekomen dat het marktaandeel van partijen in de omzet van Wmo-gefinancierde dagactiviteiten in 2019 door sluiting van een aantal locaties is teruggelopen tot $40-50 \%$. Omdat op deze locaties ook Wlz-dagactiviteiten werden verzorgd, is de positie voor deze activiteit ook teruggelopen. Bovendien zijn de toetredingsdrempels relatief laag. Het aandeel van lokale aanbieder TGB is bijvoorbeeld fors hoger in 2019 dan in de jaren daarvoor en Oma Dien heeft concrete plannen om de markt in Breda eind 2020 te betreden. Op basis hiervan concludeert de ACM dat de concentratie niet zal resulteren in mededingingsproblemen op de markt voor dagactiviteiten.

Voor wat betreft de beoordeling van de wijkverpleging worden de eerdere zorgen van de ACM wél bevestigd. Net als in Sunmeb/Corendon doet zich ook in deze concentratie de vraag voor met welke omstandigheden de ACM rekening dient te houden in haar prospectieve analyse. Partijen voeren in dit kader namelijk aan dat demografische ontwikkelingen (een toenemende vraag naar wijkverpleging) en krapte op de arbeidsmarkt maken dat slechts zeer beperkt concurrentie mogelijk is tussen zorgaanbieders van wijkverpleging. Deze ontwikkelingen zouden bovendien structureel van aard zijn en daarom moeten worden meegenomen in de beoordeling van de ACM. De ACM gaat hier echter niet in mee en benadrukt, evenals in Sunmeb/Corendon, dat de (on)zekerheid dat bepaalde ontwikkelingen zullen intreden bepalend is voor de vraag of die ontwikkelingen moeten worden meegenomen in haar prospectieve analyse. Hoewel sommige zorgaanbieders in Breda en omgeving hadden aangegeven dat het niet eenvoudig is om voldoende personeel te werven, kan uit het marktonderzoek geen eenduidige conclusie worden getrokken over de omvang van de huidige arbeidsmarktproblemen, dan wel de omvang van de vergrijzingsproblematiek voor de komende jaren in Breda en omstreken. Bovendien bestaat volgens de ACM voor partijen en overige zorgaanbieders nog voldoende mogelijkheid en prikkel om met elkaar te blijven concurreren - partijen zullen namelijk de prikkel blijven hebben om cliënten aan te trekken om zo het huidige zorgvolume te behouden waardoor zij de huidige mededingingssituatie als uitgangspunt neemt in haar inhoudelijke beoordeling. In het meldingsbesluit ging de ACM uit van één productmarkt voor wijkverpleging. Opvallend is dat partijen zich hier in de meldingsfase nog mee konden verenigen, maar zij in de vergunningsfase de ACM

12. Partijen hadden in de meldingsfase aangegeven geen inzicht te hebben in hun positie op het gebied van dagactiviteiten en de ACM heeft daarom de marktaandelen bepaald op basis van declaratiegegevens. 
ervan proberen te overtuigen dat de verschillende specialismen (bijvoorbeeld reumazorg, dementiezorg en complexe wondzorg) onderscheiden dienen te worden van de reguliere wijkverpleging en ieder een aparte productmarkt vormen. De ACM blijft echter bij haar eerdere standpunt en overweegt dat vanuit de aanbodzijde juist van belang is in hoeverre zorgaanbieders verschillende vormen van wijkverpleging als integraal pakket (kunnen) aanbieden. Het marktonderzoek wijst uit dat verschillende specialismen doorgaans worden gezien als een regulier onderdeel van de wijkverpleging en dat er bovendien mogelijkheden zijn om de bestaande zorg uit te breiden, bijvoorbeeld door inhuur van externe krachten of in samenwerking met andere zorgaanbieders. Zorgverzekeraars verwachten daarnaast ook van zorgaanbieders dat zij wijkverpleging in principe als één product aanbieden. De ACM gaat daarom uit van één productmarkt voor het aanbieden van wijkverpleging op het niveau van de gemeente.

Voor wat betreft de beoordeling van de gevolgen van de concentratie volgt de ACM voor elk van de drie gemeenten eenzelfde patroon, waarbij zij uiteindelijk alleen ten aanzien van de gemeente Breda concludeert dat de mededinging niet significant zal worden belemmerd. Hoewel Thebe en Careyn een gezamenlijk marktaandeel hebben van $40-50 \%$, blijven er door de aanwezigheid van andere zorgaanbieders voldoende keuzemogelijkheden over voor de patiënten. Van belang is hierbij nog dat vanwege het stedelijke karakter van Breda overige zorgaanbieders in staat moeten zijn om een rendabele route te verzorgen en bestaande activiteiten uit te breiden. Zorgverzekeraars staan bovendien niet onwelwillend tegenover dergelijke zorguitbreidingen, waardoor het aannemelijk is dat overige zorgaanbieders voor extra concurrentiedruk op partijen kunnen zorgen. Ten aanzien van zowel Alphen-Chaam en BaarleNassau komt de ACM echter tot de conclusie dat na de concentratie onvoldoende keuzemogelijkheden zullen overblijven. In deze gemeenten behalen Thebe en Careyn een gezamenlijk marktaandeel van respectievelijk $80-90 \%$ en $90-100 \%$ en maar weinig andere zorgaanbieders zijn hier actief. Bovendien hebben Alphen-Chaam en Baarle-Nassau een relatief ongunstige ligging met relatief weinig potentiële cliënten. Hierdoor is het voor nieuwe aanbieders lastig om naast Thebe en Careyn een structurele positie te verwerven, aangezien ook nog zou moeten worden geïnvesteerd in een lokaal netwerk en een verwijsrelatie moet worden opgebouwd met de lokale huisartsen. Deze lokale effecten vertalen zich bovendien ook naar de zorginkoopmarkt, waar volgens de ACM door de concentratie eveneens sprake zal zijn van onvoldoende keuzemogelijkheid die niet kan worden gemitigeerd door zorgverzekeraars of het zorgkantoor.

Om de geconstateerde problemen te verhelpen hebben partijen voorgesteld de activiteiten van Careyn op het gebied van wijkverpleging in de gemeenten AlphenChaam en Baarle-Nassau af te stoten. Zowel de cliënten van Careyn die woonachtig zijn in Alphen-Chaam en Baarle-Nassau als haar werknemers in deze gemeenten zullen worden overdragen aan de beoogde koper TGB. De markt reageert positief op de markttest. De ACM is er daarom voldoende van overtuigd dat het remedievoorstel van Thebe en Careyn de eerder door haar gesignaleerde problemen wegneemt en tevens uitvoerbaar en handhaafbaar is. De ACM verleent op basis van deze voorwaarden een vergunning voor deze concentratie.

\section{NCOI/LOI}

Op 13 augustus 2020 heeft de ACM een vergunning verleend voor de overname van Onderwijsgroep Nederland B.V. (LOI) door NCOI Holding B.V. (NCOI). Zowel NCOI als LOI is aanbieder van erkend hoger beroepsonderwijs (hbo), erkend middelbaar beroepsonderwijs (mbo) en niet-erkend cursorisch onderwijs.

De beoordeling van deze concentratie kenmerkt zich door het feit dat het zwaartepunt ligt bij de marktafbakening. In de meldingsfase constateerde de ACM dat zij over onvoldoende informatie beschikte om de gevolgen van de concentratie te kunnen beoordelen, waarbij zij met name moeite had met het afbakenen van de relevante markten. In de vergunningsfase heeft de ACM daarom haar onderzoek onder marktpartijen verder uitgebreid met daarnaast ook nog een enquête onder hboen mbo-studenten (van zowel NCOI en LOI als een aantal bekostigde onderwijsinstellingen).

Hoewel de ACM niet eerder markten heeft afgebakend waarop NCOI en LOI actief zijn, oordeelde zij in 2001 dat artikel $34 \mathrm{Mw}$ niet van toepassing was op een fusie tussen hogescholen. ${ }^{13}$ De ACM overwoog hierbij dat deze hogescholen voor wat betreft hun bekostigde activiteiten geen ondernemingen zijn in de zin van artikel 1 onder $\mathrm{f}$ Mw. De bekostiging speelt ook in deze concentratie een rol. Bekostigde hbo- en mbo-instellingen zijn namelijk onderwijsinstellingen die een wettelijke taak ${ }^{14}$ hebben om beroepsopleidingen aan te bieden, waarvoor zij jaarlijks van de rijksoverheid een financiële bijdrage ontvangen. Studenten die een bekostigde opleiding volgen, komen in aanmerking voor het wettelijk collegegeld dat, uitzonderingen daargelaten, lager is dan het instellingscollegegeld. Bekostigde instellingen genieten daarom het voordeel dat zij opleidingen tegen een lagere prijs kunnen aanbieden dan niet-bekostigde (private) aanbieders. Marktpartijen hebben de ACM er echter op gewezen dat hier tegenover staat dat bekostigde instellingen aan meer regelgeving moeten voldoen, waardoor niet-bekostigde instellingen meer 'regelruimte' hebben om hun opleidingen zo in te richten zoals zij dat zelf willen.

Ten aanzien van zowel het erkend hbo als erkend mbo heeft de ACM in de vergunningsfase onderzocht of een nader onderscheid dient te worden gemaakt naar (1) voltijd- en deeltijdonderwijs, (2) de financieringswijze (bekostigd en niet-bekostigd onderwijs) en (3) vakgebied. Voor het erkend hbo heeft de ACM ook nog

13. Besluit van de NMa van 11 augustus 2003, zaak 3125/44.

14. Op basis van de Wet op het hoger onderwijs en wetenschappelijk onderzoek en de Wet educatie en beroepsonderwijs. 
onderzocht of een onderscheid naar onderwijsvorm (klassikaal en afstandsonderwijs) gepast zou zijn.

Met betrekking tot het erkend hbo voeren partijen aan dat geen nader onderscheid dient te worden gemaakt tussen voltijd- en deeltijdopleidingen en vakgebied, vanwege de aanwezige aanbodsubstitutie. Het marktonderzoek levert echter een ander beeld op: voltijd- en deeltijdopleidingen richten zich namelijk ieder op hun eigen doelgroep. Waar erkend voltijd onderwijs voornamelijk de traditionele 'schoolverlater' bedient, is de deeltijdstudent veelal een oudere, werkende volwassene die zich door (kortere) trajecten wil laten om- of bijscholen. Voltijd en deeltijd erkend hbo moeten daarom als aparte productmarkten worden gezien.

De activiteiten van partijen overlappen slechts op deeltijd hbo en de ACM beoordeelt voor het overige daarom in hoeverre binnen dit segment een nader onderscheid moet worden gemaakt tussen bekostigde en niet-bekostigde opleidingen, vakgebied en onderwijsvorm. Uit het marktonderzoek volgt dat binnen het deeltijdsegment bekostigde en niet-bekostigde onderwijsinstellingen wel degelijk met elkaar concurreren om dezelfde groep studenten en dat onderwijsinstellingen in toenemende mate overgaan op blended learning, waardoor klassikaal en afstandsonderwijs steeds dichter naar elkaar toegroeien. Voor de beoordeling van de gevolgen van deze concentratie gaat de ACM daarom uit van een markt voor erkend deeltijd hbo. Of er een onderscheid moet worden gemaakt naar vakgebied laat de ACM uiteindelijk in het midden.

Voor wat betreft de geografische marktafbakening gaat de ACM uit van een markt die regionaal en mogelijk nationaal van omvang is.

$\mathrm{Na}$ de uitgebreide aandacht voor de marktafbakening heeft de ACM de beoordeling van de gevolgen van de concentratie snel gemaakt. Het gezamenlijk marktaandeel van partijen op het deeltijd hbo geeft op zichzelf namelijk geen reden tot zorgen. Zonder de overige nietbekostigde instellingen mee te nemen, behalen NCOI en LOI op landelijk niveau een marktaandeel van 20-30\%. In bepaalde arbeidsregio's hebben NCOI en LOI ten hoogste een marktaandeel van $40-50 \%$, waarbij overige marktpartijen aangeven dat de concurrentie tussen bekostigde en niet-bekostigde instellingen zal toenemen. De ACM concludeert daarom dat er geen aanwijzingen zijn dat de concentratie zal leiden tot een significante beperking van de mededinging op het gebied van erkend deeltijd hbo.

De beoordeling van het erkend mbo volgt grotendeels de beoordeling van het erkend hbo. Ook hier constateert de ACM het bestaan van verschillende doelgroepen voor voltijd- en deeltijdopleidingen. Anders dan voor het hbo is in het mbo echter wel degelijk sprake van aanbodsubstitutie tussen voltijd- en deeltijdopleidingen. Volgens marktpartijen zijn hiervoor geen aanzienlijke investeringen nodig, wat onder meer wordt ondersteund door het feit dat ook bekostigde mbo -instellingen zich in toenemende mate richten op het aanbieden van bestaande opleidingen in een deeltijdvariant. Hoewel de activiteiten van NCOI en LOI slechts overlappen op het deeltijdsegment - en de ACM de gevolgen daarom beoordeelt op dit segment - laat zij in het midden of de markt ook voltijd erkend mbo omvat.

Evenals voor het erkend hbo geven het marktonderzoek en de enquête geen aanleiding om binnen het deeltijdsegment een nader onderscheid te maken op basis van financieringswijze of vakgebied. Voor wat betreft de geografische afbakening zijn voor het mbo sterkere aanwijzingen dat de markt regionaal in omvang is. Dit komt met name door het feit dat vanwege de praktijkelementen binnen mbo-opleidingen, de binding met de regio sterker is. Voor haar beoordeling laat de ACM de exacte geografische marktafbakening uiteindelijk in het midden.

Net als voor het erkend hbo concludeert de ACM ook ten aanzien van erkend deeltijd mbo dat de concentratie niet zal leiden tot een significante beperking van de mededinging. Het concurrentieel landschap van de mbo-instellingen kenmerkt zich door regionaal sterke (bekostigde) onderwijsinstellingen die over een significante marktpositie beschikken. NCOI en LOI zullen daarom in geen enkele regio een zodanige positie verwerven dat zij in staat zullen zijn om de mededinging ongunstig te beinvloeden. Ook na de concentratie zullen daarom voldoende keuzemogelijkheden overblijven, zowel vanuit de bekostigde als niet-bekostigde hoek. Ook voor wat betreft het mbo acht de ACM het daarom niet aannemelijk dat de concentratie niet zal resulteren in een significante beperking van de mededinging.

Uit het meldingsbesluit kan worden afgeleid dat de ACM ten aanzien van het niet-erkend cursorisch onderwijs (NECO) nog het meest in het duister tastte over de marktafbakening. Het NECO kenmerkt zich namelijk door een hoge mate van heterogeniteit van producten en omvat alle opleidingen die niet resulteren in een wettelijk erkend diploma. Het gaat hierbij enerzijds om korte, van erkende opleidingen afgeleide programma's en cursussen en anderzijds om (praktijk)trainingen die zich richten op zowel zakelijke als particuliere afnemers. In de vergunningsfase heeft de ACM nader onderzocht of de markt voor NECO nader zou moeten worden gesegmenteerd op basis van (1) type afnemer en/of (2) vakgebied en/of (3) omvang van de aanbieder. Partijen stellen zich op het standpunt dat sprake is van een ruime markt voor het aanbieden van NECO en baseren zich hierbij met name op de volgens hen aanwezige aanbodsubstitutie. Ook ten aanzien van het NECO levert het marktonderzoek geen eenduidig beeld op, met name voor wat betreft het mogelijke onderscheid tussen zakelijke en particuliere afnemers. Vanuit de aanbodzijde wijzen aanbieders op de verschillen in marketing, prijszetting en inzet van docenten tussen het bedienen van zakelijke en particuliere afnemers. Bovendien hechten zakelijke afnemers volgens marktpartijen meer waarde aan (de mogelijkheden voor) maatwerk, waar particulieren vragen om flexibiliteit qua tijdsindeling. Hoewel de ACM op basis hiervan erkent dat het verschil tussen onderwijs aan zakelijke en particuliere klanten kenmerken vertoont van twee aparte (deel)markten binnen NECO, gaat zij niet zo ver dat zij 
oordeelt dat ook daadwerkelijk sprake is van twee aparte productmarkten. Marktpartijen menen namelijk ook dat inhoudelijk de cursussen voor het zakelijke segment niet wezenlijk verschillen van de cursussen die aan particulieren zouden kunnen worden aangeboden. De ACM gaat daarom uit van een nationale markt voor NECO, zonder nadere segmentering.

Hoewel de hiervoor beschreven marktafbakening mogelijk anders doet vermoeden, kijkt de ACM voor de beoordeling van de gevolgen van de concentratie naar specifieke deelsegmenten binnen het NECO. Aangezien er voldoende aanwijzingen zijn dat de concurrentie per (deel)segment van NECO verschilt, beoordeelt de ACM achtereenvolgens de volgende deelsegmenten: (a) NECO dat is afgeleid van wettelijk erkend hbo en mbo, (b) NECO gericht op zakelijke afnemers en (c) NECO gericht op particuliere afnemers. Voor elk van deze deelsegmenten concludeert de ACM uiteindelijk dat het niet aannemelijk is dat de concentratie de concurrentie significant zal belemmeren. Op deelsegment (a) acht de ACM het aannemelijk dat partijen, naast bestaande aanbieders van NECO, (in toenemende mate) concurrentie ondervinden vanuit erkende (bekostigde) instellingen. Ook na de concentratie zal daarom voldoende concurrentiedruk worden uitgeoefend op partijen. Ook voor wat betreft deelsegment (b) is er onvoldoende aanleiding tot zorgen. De overlap tussen partijen is slechts beperkt - anders dan NCOI richt LOI zich namelijk vooral op particulieren - en uit het marktonderzoek zijn geen signalen gekomen dat partijen na de concentratie een dominantie positie zouden verkrijgen op een van de vakgebieden binnen het NECO. Ten slotte de beoordeling voor deelsegment (c). De ACM constateert op basis van het marktonderzoek dat er op dit moment naast NCOI en LOI slechts twee andere spelers zijn - NHA en Laudius - die een relatief ruim pallet aan opleidingen aanbieden aan particulieren. Wanneer slechts naar dit type aanbieder wordt gekeken, zullen partijen volgens overige marktpartijen na de concentratie een marktaandeel van meer dan $50 \%$ behalen. Volgens de ACM zal er echter per vakgebied ook na de concentratie nog voldoende concurrentiedruk uitgaan van alternatieve aanbieders - zowel vanuit NHA en Laudius als vanuit diverse kleinere aanbieders en gespecialiseerde nichespelers. Het marktonderzoek wijst ten slotte uit dat sterke groei vanuit spelers binnen een relatief korte termijn mogelijk is. Op basis hiervan concludeert de ACM dat het niet aannemelijk is dat de concentratie zal resulteren in een significante beperking van de mededinging op het deelsegment particulier-NECO. Op basis van het voorgaande verleent de ACM een vergunning voor de overname van LOI door NCOI.

\section{Conclusie}

In 2020 passeerden in de concentratiecontrole diverse maatschappelijk relevante onderwerpen de revue. Zo moest de ACM in DPG/Sanoma de aanwezigheid van mediapluriformiteit meenemen in haar beoordeling en beoordeelde zij in $N C O I / L O I$ in hoeverre studenten nog over voldoende keuzemogelijkheden zouden beschikken voor het volgen van erkende en niet-erkende opleidingen en cursussen. Daarnaast heeft de ACM zich meerdere keren gebogen over de vraag welke toekomstige (maatschappelijke) ontwikkelingen meegenomen dienden te worden in haar beoordeling. In Sunmeb/ Corendon en Thebe Wijkverpleging/Stichting Careyn achtte de ACM de gevolgen van de COVID-19-crisis in de reissector en demografische ontwikkelingen onvoldoende zeker en structureel van aard om mee te nemen in haar beoordeling. In $N S / P O N$ kwam de ACM ten aanzien van de MaaS-diensten juist tot de conclusie dat toekomstige ontwikkelingen ertoe zouden leiden dat er een afzonderlijke markt voor geïntegreerde MaaS-oplossingen zou ontstaan en eiste zij toezeggingen van partijen ondanks een zeer geringe positie van partijen op de markt voor MaaS-oplossingen (een gezamenlijk marktaandeel van $0-5 \%$ ). Het $\mathrm{CBb}$ bevestigde (nogmaals) dat voor de beoordeling van de gevolgen van een concentratie de ACM de relevante markt niet (altijd) definitief hoeft af te bakenen. Een andersluidend oordeel zou verstrekkende gevolgen kunnen hebben, zeker nu onder meer door digitalisering de huidige marktdynamieken aan (vergaande) verandering onderhevig zijn, hetgeen het afbakenen van relevante markten (nog) complexer maakt. Bestaande markten schuiven dichter naar elkaar toe en ook nieuwe markten zijn in opkomst, hetgeen de ACM bijvoorbeeld uitdrukkelijk meenam in haar beoordeling in NS/Pon. Dat de ACM veel werk heeft aan de marktafbakeningsexercitie blijkt uit haar concentratiebesluiten van 2020 en dit zal in de nabije toekomst vermoedelijk niet veranderen. 